\title{
Seed Coating Formulations for Improving Rhizobia Survival, Growth, and Grain Yield of Common Bean
}

\author{
Marwanto $^{\mathrm{a},{ }^{*}}$, Merakati Handajaningsih ${ }^{\mathrm{a}}$, Bambang Gonggo Murcitro ${ }^{\mathrm{b}}$ \\ ${ }^{a}$ Department of Agronomy, Faculty of Agriculture, University of Bengkulu, Bengkulu, 38371A, Indonesia \\ Email: "pak.marwanto50@gmail.com \\ ${ }^{b}$ Department of Soil Science, Faculty of Agriculture, University of Bengkulu, Bengkulu, 38371A, Indonesia
}

\begin{abstract}
Coating legume seeds with Rhizobia have met a little success because of the difficulty in supporting bacterial survival on the seed coating agent. Accordingly, these studies aimed (i) to determine the best seed coating formulations to maintain the survival of Rhizobium phaseoli population on the surface of coated bean seed over a storage period of 0,24 , and 48 hours at $40^{\circ} \mathrm{C}$ for laboratory trial, and (ii) to evaluate the best formulations for common bean growth and yield for field trial. Twelve seed coating formulations (SCFs) were used to coat garden bean seeds for the two studies. The results showed that four SCFs were the best for $R$. phaseoli survival throughout the storage period. They contained combinations of gum arabic and peat moss (100\%), gum arabic and peat moss+biochar $(25 \%: 75 \%)$, carboxymethyl cellulose and peat moss $(100 \%)$, and carboxymethyl cellulose and peat moss+biochar (25\%:75\%). These four Rhizobia seed-coating formulations also promoted the best common bean growth and yield based on nodule number, plant dry weight, and grain yield indicators. Overall, these studies suggest that the four SCFs promoted the highest increase in nodulation, plant biomass production, and grain yield due to their ability to maintain the highest survival of $R$. phaseoli population on the surface of coated bean seed.
\end{abstract}

Keywords - seed coating; rhizobium inoculant; inoculant carrier; adhesive; bean seed.

\section{INTRODUCTION}

As an essential grain legume, common bean (Phaseolus vulgaris L.) also called a garden bean, green bean, or dry bean develops mutual partnerships with soil bacteria known as Rhizobia. This legume-Rhizobia symbiosis is responsible for the establishment of biological nitrogen fixation (BNF) through the formation of nodules on common bean roots [1]. In this mutualism, BNF is responsible for enhancing soil fertility by fixing atmospheric nitrogen $\left(\mathrm{N}_{2}\right)$ [2]. Meanwhile, garden bean plays crucial roles for more than 300 million people diets in the tropics by supplying protein, carbohydrate complex, and micronutrients such as iron, zinc, thiamine, and folic acid for food [3], [4]. Parts of this crop containing these high nutritional substances for human foods include green leaves, green pods, immature, and mature seeds, while stems or straws function as fodder for animal feed.

The worldwide garden bean production per year is estimated at 12 million tons [3]. In Indonesia, a general review of four years' reports from 2011 to 2014 showed that production reduced gradually from 334,669 tons in 2011 to 318,328 tons in 2014 [5]. The decline in production in
Indonesia and other tropical parts of the world occurred because this crop is cultivated by intercropping in areas characterized by low soil nutrient availability and low rainfall throughout its growing season [6]. Meanwhile, garden bean consumption increased from 0.826 $\mathrm{kg} /$ capita/year in 2014 to $1.1147 \mathrm{~kg} /$ capita/year in 2015 [5]. In years to come, the Indonesian farm will face a considerable challenge primarily to meet the increasing need for protein and micronutrients from this crop due to an increase in the Indonesian population. Therefore, increasing garden bean production is crucial to meet the demand of the increasing Indonesian population.

Soil characteristics of most common bean production areas in the world, especially in Indonesia and other tropical countries, are low nutrient and soil moisture availability [7]. Due to these unfavorable ecosystems, the most common practice by local farmers for increasing its yield is to apply an enormous amount of inorganic fertilizers routinely in their crop fields to compensate nitrogen insufficiency [8].

In the recent past, the use of fertilizers has promoted higher crop yields. However, the same approaches today are failing to guarantee similar improvements [9]. The abuse of fertilizers, which is presently observed in modern, intensive agriculture, is the source of many undesirable effects on the 
environment, soil health [10] as well as adverse effects on human health [11] and soil-flora [12]. The loss of beneficial soil microorganisms made agricultural lands unproductive for future use.

Among synthetic fertilizers used, $\mathrm{N}$ is one of the essential mineral fertilizers for plant growth and development applied commonly in the form of urea containing $46 \% \mathrm{~N}$ [13]. Only a small portion of applied $\mathrm{N}$ fertilizer was used directly by the plant [9]. More than $50 \%$ of the applied $\mathrm{N}$ fertilizer is lost through different processes, e.g., emission in the form of nitrous oxide gas and leaching in the form of nitrate. Nitrous oxide is a kind of greenhouse gas with an impact on global warming comparable to that of CFCs, and its emission causes air pollution [14]. Nitrate leaching also endangers human health because it makes water and food contaminated [9]. Consequently, an alternative approach, such as ecofriendly sustainable agriculture methods, has become an option to improve crop yield.

The use of plant growth-promoting rhizobacteria (PGPR) such as atmospheric $\mathrm{N}$ fixing bacteria termed Rhizobium currently becomes an option to support the eco-friendly sustainable agriculture. These beneficial microorganisms develop a mutual partnership with common bean and other leguminous crops resulting in biological nitrogen fixation (BNF) [15]. Like other legumes, garden bean partnership with Rhizobium, also known legume-Rhizobium symbiosis, is characterized by nodule formation in their roots [16].

Leguminous crops in partnership with Rhizobium are tremendously crucial because these useful microorganisms can fix the atmospheric $\mathrm{N}$ and then convert it into usable forms. They can fix about 44-66 million tons of $\mathrm{N}_{2}$ annually and convert it into usable forms to compensate nearly half of all the $\mathrm{N}$ used in the agriculture world [17]. The worldwide contribution of $\mathrm{N}_{2}$ fixed by legumes nodules such as pulses and oilseeds legumes are about 21.45 tons annually to global agricultural systems [14], [18]. Thus, Rhizobium can be used as a promising alternative to synthetic $\mathrm{N}$ fertilizers. The application of Rhizobium in the form of Rhizobium inoculant not only increased soil fertility but also enabled to minimize the deleterious effects of the continued excessive use of $\mathrm{N}$ fertilizer [19]. With this beneficial association, common bean and other legume crops allow us to meet its all $\mathrm{N}$ need.

The fruitful association between $\mathrm{N}_{2}$-fixing bacteria with legumes was able to be achieved by inoculation [20]. Inoculation is the addition of efficient Rhizobium to leguminous seeds before planting to promote symbiotic $\mathrm{N}$ fixation [9], [21]. In most soils, Rhizobium inoculation is necessary due to the uncertain presence of the active Rhizobium species or an insufficient number of the active Rhizobium to form root nodules [10], [15]. Also, it provides some advantages such as prevention on early $\mathrm{N}$ deficiency, the reduced demand of the leguminous crop upon soil $\mathrm{N}$, an increase in crop yield, and improved crop quality [15], [21].

Different formulations of $\mathrm{N}$-fixing bacteria inoculant have been developed either in the form of liquid or solid. The use of a liquid polymer such as alginate, or polyacrylamide was familiar as a carrier material for liquid inoculant [22]. Meanwhile, a solidified material such as peat, clay, or vermiculite was utilized as a carrier material for stable inoculant [15]. The liquid inoculant was commonly applied in the form of spray inoculation, soil drenches, or root dipping, while the solid inoculant inoculated in-furrow at the time of planting [15]. The application of these inoculation techniques ended up with success for soybean [23]. However, they were not applicable for large-scale purposes due to concern on the high amount of microbial inoculum used [15]. Inoculation on the seeds via seed coating enabled to overcome these drawbacks [15], [21], [24].

Seed coating is a technique where specific external materials containing a sticking agent are applied by mixing with the seed until uniform coverage is achieved on the seed surface with the purpose of enhancing seed performances [25]. Seed coating was considered the most practical way of inoculation because of its proven benefits [20], [25]. Seed coating reduced the use of inoculant amounts, enabling to minimize cost production and increase efficiency. Also, it positioned the inoculants in immediate contact with germinating seeds so that the microbial inoculant infected and colonized seedling roots directly and finally protected the seedling roots against soil-borne disease and pests. Coating the seed surface with either solid or liquid bacterial formulations affected the effectiveness of the partnership between $\mathrm{N}_{2}$-fixing bacteria and soybean plants [20], [24].

The previous study on seed coating demonstrated that the effectiveness of seed coating as a delivery system for arbuscular mycorrhizal (AM) fungal inoculum was like that of conventional soil inoculation [25]. Also, seed coating for AM fungi delivery was more beneficial than conventional soil inoculation due to less amount of infective inoculum used and chemical fertilizer applied. Another experiment studied the effect of biochar inoculant, and seed coating on soybean revealed that the application of inoculated biochar via seed coating promoted the formation of effective nodules [24].

In practice, a method of preparing coated seed consisted of slurring seeds with an inoculant composition containing a beneficial microorganism, an adhesive agent, and a carrier medium [26]. Concerning the beneficial microorganism, only specific bacterial strains symbiotically associated with specific crops so that infection of these strains into the root of different crops did not occur. Thus, the selection of effective Rhizobium strain together with the evaluation of appropriate carrier material for this strain was crucial to guarantee the efficiency of the inoculant in the field [27].

When delivered via seed coating, Rhizobium inoculant compositions commonly consist of appropriate Rhizobium strain culture mixed with a solid-based carrier. The inoculant is put in intimate contact with the seed via an adhesive agent to assure a quick formation of nodules in crop plants after germination. The adhesive agents function to attach the Rhizobia to the seeds, thus securing the required intimate touch between the Rhizobium and the newly emerged roots. Thus, the adhesives used should have good coating properties such as non-phytotoxic, readily biodegradable, environmentally safe, excellent moisture retention, and inexpensive [27].

Beside good coating characteristics, adhesive agents should protect Rhizobia cells applied to seed against stressful environmental conditions such as elevated temperature and low soil moisture availability [28]. Even in practice, the temperature of the soil can be higher than $40^{\circ} \mathrm{C}$ during the midday in tropical regions. Exposure of inoculated seeds to 
these adverse conditions is inevitable because the inoculated seeds are shown into a furrow. The two field conditions are known as the most important environmental factors affecting survival and $\mathrm{N}_{2}$ fixing the effectiveness of Rhizobia [28]. At last, good adhesive agents should be able to provide energy sources as food for them.

Owing to its excellent coating characteristics, complete biodegradability, and renewability, adhesive agents such as GA, CMC, and sucrose, are considered as promising candidates for seed inoculant adhesive agents. The use of these adhesives for commercial microorganism inoculation was a common practice due to its successful role on promoting the survival of Rhizobia cells applied to seed against unfavorable conditions in the field and storage room [27]-[29].

The success of seed-coat inoculation depends not only on adhesive agents but also on suitable carrier materials used. The primary criterion of a carrier used is to have an excellent ability to support the survival of Rhizobia cells applied to seed by offering protection against unfavorable conditions in the rhizosphere [30]. To ensure this, the carrier used should have properties that meet the needs of the microbial physiology. The properties include high water holding capacity, $\mathrm{pH}$ buffering capacity, cation, and anion exchange capacity, non-toxic to Rhizobia, and excellent adhesion to seed, and easy to sterilize, readily and inexpensively available, and high survival during storage for industrial requirements [30].

The most common inoculant carrier used at a commercial scale is irradiated peat because it meets most of the criteria listed above [30]-[32]. However, peat is a non-renewable resource, and its excessive use is a significant environmental concern. Moreover, its limited reserves have led to price increases, which ultimately restricts its use [30]. Therefore, it is necessary to seek alternative carriers to peat that can retain the viability of bacteria for long periods without loss of effectiveness [24], [33].

To be comparable with peat carriers, an excellent bacterial carrier as a substitute for irradiated peat must have some essential characteristics such as abundant, locally available, and cheap. It should also have a good ability to absorb and store water and good aeration properties. More importantly, the satisfactory substitute enables to support high rates of bacterial growth and survival ( $10^{8}$ forming colony units) for a long time in storage. Also, it retains the suitable number of viable microbial cells when applied on seed as seed-coat inoculation or in soils under unfavorable conditions as a soil inoculation [24], [33]. Additionally, the right inoculant carrier should be non-poisonous, eco-friendly, and quickly made, sterilized and managed in the field. At last, it should promptly release bacteria into the soil, be easily converted to a powder, mixable, packageable and attach to the seed [32].

The use of many alternative carrier materials as Rhizobium carriers such as organic polymers [30], [34], agricultural waste (corn cob and plant compost) and organic minerals (vermiculite and perlite) [31], [34], [35] had met a little success. Recently biochar has become of great interest in regards to its good potentials in several environmental issues [12], [32]-[37].

Although the study on the role of biochar as a potential inoculant carrier has not been intensive, previous studies on the potential use of biochar as carrier materials for introducing PGPR into soils demonstrated good results. For example, biochar was an effective carrier for the preparation of Burkholderia sp. L2 for tomato [12], Pseudomonas libanensis for corn [24], Pseudomonas putida UW4 [32, Enterobacter cloacae UW5] [33], Rhizobium tropici [36], Rhizobia phaseoli for kidney bean [37], Bradyrhizobium japonicum for soybean [38], Bradyrhizobium sp. for lupin [39].

Biochar is an excellent, porous carbon-rich product generated from biomass pyrolyzes such as woody feedstock materials, organic wastes (compost), and agricultural crop residues at a high temperature $\left(>400^{\circ} \mathrm{C}\right)$ under the complete or partial absence of oxygen [40]. Previous research demonstrated that physicochemical properties of biochar such as $\mathrm{pH}$, porosity, pore dimensions, surface area, the content of labile organic carbon, and other fraction of mineral constituents are different depending on raw materials for biochar production, pyrolysis temperature, and production processes [41]. Therefore, it is still necessary to understand specific biochar derived from a particular raw material such as oil palm empty fruit bunch (EFB) for inoculant carrier.

As stated earlier that different biochar generated from pyrolysis of different raw materials have been studied for preparation of different inoculum carriers. These studies demonstrated that biochar could be used as useful inoculum carriers for different PGPRs when applied on seeds as seedcoat inoculation and in soils as soil inoculation. Even though none of these studies has targeted biochar primarily derived from oil palm EFB pyrolysis.

The use of many raw materials for biochar production was possible. In Indonesia, a prospective raw material for biochar production is oil palm EFB from the industrial palm oil sector. This oil palm waste is produced in large quantities approximately 4.2 million ton each year [42]. The gradual accumulation or improper disposal of this waste will generate environmental problems. Therefore, immediate action to make the best use of this valuable resource where its availability is abundant by converting it into biochar. Due to useful advantages and potential chance of the use of biochar for biological inoculant preparation, the present study aimed (i) to determine which the seed coating formulations best maintains the survival of $R$. phaseoli population on the surface of coated bean seed based on CFU count at an interval of 24 hours for a storage period of 48 hours at $40^{\circ} \mathrm{C}$, and (ii) to evaluate which the seed coating formulations best promotes common bean growth and yield.

\section{MATERIALS AND METHODS}

This study consisted of two series of experiments. They were conducted from March to June 2015 at Agronomy Laboratory and Plant Protection Laboratory for the first experiment and Agriculture Faculty Research Plot Bengkulu University for the second experiment. In brief, a series step in doing these trials included (1) preparation saturated $R$. phaseoli liquid culture, (2) preparation and characterization of biochar-based carriers, (3) inoculant production, (4) development of adhesive agents, and (5) seed coating formulation and inoculation. 


\section{A. Preparation of Saturated Bacterial Liquid Culture}

The first and second trials employed Rhizobium phaseoli culture collection. The bacteria was proliferated by aseptically maintained in yeast extract-mannitol (YEM) medium) in rotary shaker cultures $(200 \mathrm{rpm})$ at $25^{\circ} \mathrm{C}$ for four days until late log-phase [43]. The content of YEM broth used consisted of $1.0 \%$ mannitol, $0.1 \%$ yeast extract, $0.066 \%$ $\mathrm{KH}_{2} \mathrm{PO}_{4} 3 \mathrm{H}_{2} \mathrm{O}, 0.02 \% \mathrm{MgSO}_{4} 7 \mathrm{H}_{2} \mathrm{O}, 0.01 \% \mathrm{NaCl}$, and $1.5 \%$ agar (Difco Lab., Detroit, Mich.). After four days of incubation, a late log-phase culture of $R$. phaseoli was plated onto Petri dishes to evaluate the condition and viability of the population. Serial dilutions and plate count methods were employed to count viable bacteria [44]. With this method, serial dilutions of duplicate samples of the late logphase period were prepared to range from $10^{-4}$ to $10^{-7}$ on YMA+Congo Red. The number of viable Rhizobia cells was quantified and expressed in colony-forming units (CFU). The calculated broth culture cell density was about $4.1 \times 10^{7}$ cells (CFU) $\mathrm{ml}^{-1}$. The culture was employed as an inoculant for inoculating the carrier preparations.

\section{B. Origin of Carrier Materials, Carrier Preparation and Characterization, and Inoculant Production}

Throughout this study, biochar (BC) and peat moss (PM) ) in four different proportions were used to prepare $R$. phaseoli inoculant carriers. The four combinations were the following: $\mathrm{BC}(100 \%)$, PM (100\%), BC+PM (50\%:50\%), and $\mathrm{BC}+\mathrm{PM}(25 \%: 75 \%)$. The local material used for making $\mathrm{BC}$ was oil palm EFB, a lignocellulosic biomass waste product of the palm oil mills. The EFB was collected from local private palm oil mills in Bengkulu and was converted to biochar via slow pyrolysis at about $400^{\circ} \mathrm{C}$ for eight hours in a kiln. Meanwhile, peat moss was collected from the swampy area located in Bengkulu University Campus, Bengkulu, and then sun-dried for the next use.

A method was adopted with a little modification to prepare inoculant carriers [45]. One hundred grams of each carrier materials were taken, reduced their moisture content by separately oven-drying at $75^{\circ} \mathrm{C}$ for three days continuously, and milled to a powder. The milled carrier with different sizes was separated by a screen of 100 mesh $(150 \mu \mathrm{m})$. The powdered carrier fraction that passed the sieve was gathered and put into a collecting pan. The remnant was brought back to the mill, finely powdered, and sieved again.

The milled $\mathrm{BC}$ and $\mathrm{PM}$ were then combined in four different proportions (BC: 100\%; PM: 100\%; BC+PM: 50\%:50\%; BC+PM: 25\%:75\%). PM was used in this study as the standard inoculant carrier or as a control. The four carriers were called biochar-based carriers for simplicity and tested as a carrier of $R$. phaseoli inoculant.

BC $(100 \%)$ and PM (100\%) were made by weighing 200 $\mathrm{g}$ of each carrier material separately. Meanwhile, mixing 100 $\mathrm{g}$ of $\mathrm{BC}$ and $100 \mathrm{~g}$ of $\mathrm{PM}$ was employed for $\mathrm{BC}+\mathrm{PM}$ (50\%:50\%), and $50 \mathrm{~g}$ of $\mathrm{BC}$ and $150 \mathrm{~g}$ of PM for $\mathrm{BC}+\mathrm{PM}$ (25\%:75\%). The four carriers were placed in autoclavable polypropylene bags and sterilized for 60 minutes at $121^{\circ} \mathrm{C}$.

Characterization of each biochar-based carrier was performed by measuring moisture content (MC) and $\mathrm{pH}$. The MC of each biochar-based carrier was standardized by mixing $5 \mathrm{ml}$ water for every $10 \mathrm{~g}$ carrier. The reduction in weight of the sample before and after oven-drying was used to calculate the resulting $\mathrm{MC}$.

The $\mathrm{pH}$ of each biochar-based carrier was measured according to [46] with a minor change. Briefly, $10 \mathrm{~g}$ of each of the carriers and $90 \mathrm{ml}$ water were put together in a $400 \mathrm{ml}$ glass beaker with continuous mixing with a stirrer glass rod. The $\mathrm{pH}$ of the mixture was checked with a Corning $\mathrm{pH}$ meter. As a control treatment, the pH of PM (100\%) was standardized at about $6.5-7.0$ by adding powdered calcium carbonate $\left(\mathrm{CaCO}_{3}\right)$. The amount of $\mathrm{CaCO}_{3}$ required to neutralize $10 \mathrm{~g}$ of the carrier was documented. Then, the corresponding amount of $\mathrm{CaCO}_{3}$ to make the remaining carrier neutral was computed. Meanwhile, the resulting $\mathrm{pH}$ for the other three inoculant carriers was not adjusted to neutral.

The previous procedure was used to sterilize the carrier[45]. Each of the four prepared carriers was ovendried at $70^{\circ} \mathrm{C}$ until their dry weight was constant, put in polypropylene bags, and sanitized by autoclaving for 20 minutes at $121{ }^{\circ} \mathrm{C}$ for three consecutive days.

\section{Preparation of Inoculated Biochar-Based Carriers}

All inoculants were made by aseptically inoculating each ground biochar-based carrier with saturated $R$. phaseoli liquid culture and then mixing it thoroughly. The method developed by [45] was adopted with a little modification to inoculate biochar-based carriers with $R$. phaseoli culture. Sterilized $250 \mathrm{~cm}^{3}$ plastic bags were prepared for mixing the four biochar-based carriers and saturated $R$. phaseoli liquid culture. About $30 \mathrm{~g}$ of each of cleaned biochar-based carriers was aseptically put into the bags, added with $1.2 \mathrm{ml} R$. phaseoli culture in late log-phase $\left(4.1 \times 10^{7} \mathrm{CFU} \mathrm{ml}^{-1}\right)$, mixed with $11.0 \mathrm{ml}$ of sterile water to achieve the desired final moisture content of each carrier in the range of $40 \%$ to $45 \%$, sealed the bags in such a way that proper aeration for the inoculant was achieved inside the bags by allowing about $70 \%$ space inside the bags to remain empty. Then, the bags were stored in a dry place at $28-30^{\circ} \mathrm{C}$ for one week before use. After seven days of incubation, the cell density in all inoculated biochar-based carriers was separately calculated by adding $10 \mathrm{~g}$ of each inoculated biochar-based carrier to $90 \mathrm{ml}$ of sterile deionized water and performing a 10-fold dilution series. Then, $0.1 \mathrm{ml}$ aliquots of the appropriate dilutions were spread on YEM agar plates. The plates were stored at $28-30^{\circ} \mathrm{C}$ for three days. After storage, the bacterial cell density (CFU per milliliter) in each inoculated biocharbased carrier was immediately counted. Each inoculated carrier contained $\pm 1.26 \times 10^{7}$ viable cells $\mathrm{g}^{-1}$ when used to inoculate seed via seed coating.

\section{Preparation of Coating Adhesives}

Coating adhesives tested in this study consisted of three levels: 20\% Gum Arabic (GA), 2\% sodium carboxymethyl cellulose (CMC), and 10\% household sucrose (SC). About $20 \mathrm{~g}$ granular GA divided into small lots ( $2 \mathrm{~g}$ each lot) was dissolved in near-boiling water while continuously mixing the solution with a magnetic stirrer to prepare $20 \%$ GA. After being suspended, the second lot of $2 \mathrm{~g}$ granular GA was then added while stirring. This procedure was repeated many times until a total of $20 \mathrm{~g}$ granular GA had been added. The solution $\mathrm{pH}$ was maintained at a neutral 
level by adding $2.5 \mathrm{~g}$ of precipitated $\mathrm{CaCO}_{3}$ to the $\mathrm{GA}$ solution while stirring until $\mathrm{CaCO}_{3}$ was entirely dissolved. The GA solution was kept in a refrigerated room before used.

The solution of $2 \% \mathrm{CMC}$ was made by adding dry CMC in small lots ( $2 \mathrm{~g}$ each lot) in $1000 \mathrm{ml}$ of deionized water at $25^{\circ} \mathrm{C}$ while continuously blending the solution with a magnetic stirrer. After being dissolved, the second lot of $2 \mathrm{~g}$ CMC was then added while mixing. This procedure was repeatedly duplicated until a total of $20 \mathrm{~g}$ CMC had been added while a $10 \%$ SC solution was produced by dissolving $100 \mathrm{~g}$ household sugar in $1000 \mathrm{ml}$ of deionized water while continuously mixing the solution.

\section{E. Preparation of Seed Coating Formulations and Seed Coating Inoculation}

To prepare the 12 seed coating formulations, the previously developed biochar-based carriers inoculated with saturated $R$. phaseoli liquid culture and coating adhesives were employed. The formulations were made by combining the four levels of inoculated carriers and the three levels of coating adhesives, resulting 12 seed coating formulations. These coating formulations were applied to perform seed coating inoculation. The detailed formulations is presented in Table I.

TABLE I

COMPOSITION OF SEED COATING FORMULATIONS (SCF)

\begin{tabular}{|c|c|c|c|c|}
\hline \multirow{2}{*}{$\begin{array}{c}\text { Coating } \\
\text { Adhesives }\end{array}$} & \multicolumn{4}{|c|}{ Biochar-Based Carriers Proportions } \\
\cline { 2 - 5 } & $\begin{array}{c}\mathrm{PM} \\
(100 \%)\end{array}$ & $\begin{array}{c}\mathrm{BC} \\
(100 \%)\end{array}$ & $\begin{array}{c}\mathrm{BC}+\mathrm{PM} \\
(50 \%: 50 \%)\end{array}$ & $\begin{array}{c}\mathrm{BC}+\mathrm{PM} \\
(25 \%: 75 \%)\end{array}$ \\
\hline $20 \% \mathrm{GA}$ & $\mathrm{SCF}_{1}$ & $\mathrm{SCF}_{2}$ & $\mathrm{SCF}_{3}$ & $\mathrm{SCF}_{4}$ \\
\hline $2 \% \mathrm{CMC}$ & $\mathrm{SCF}_{5}$ & $\mathrm{SCF}_{6}$ & $\mathrm{SCF}_{7}$ & $\mathrm{SCF}_{8}$ \\
\hline $1 \% \mathrm{SC}$ & $\mathrm{SCF}_{9}$ & $\mathrm{SCF}_{10}$ & $\mathrm{SCF}_{11}$ & $\mathrm{SCF}_{12}$ \\
\hline
\end{tabular}

For each seed coating formulation, a ratio of 1:2:20 (adhesive: inoculant: seed weight or volume) was used. For example, $50 \mathrm{ml}$ of each adhesive agent was needed for every $100 \mathrm{~g}$ of solid inoculant and $1000 \mathrm{~g}$ of seed coated. Each solid inoculated carrier contained $\pm 1.26 \times 10^{7}$ viable cells $\mathrm{g}^{-1}$ when used to inoculate seed via seed coating.

The method developed was applied with a minor adjustment to perform seed coating inoculation [45]. Common bean seed cv Aurora was obtained from a local market and subjected to viability test at the Agronomy Laboratory, Bengkulu University, to assess its initial seed quality by the standard germination test. Before coating, bean seeds were surface-sterilized and dried to eliminate microorganisms. Surface sterilization was performed in batches of $1000 \mathrm{~g}$ of seeds by soaking in $70 \%$ alcohol for five minutes and rinsing with sterile distilled water five times. The seeds were then dried in a laminar hood for two hours.

After sterilization, the seeds were aseptically moistened with distilled water before coating. Seed coating was accomplished with a little change [45]. The surface-sterilized seeds (in a batch of $1000 \mathrm{~g}$ ) were pre-coated with each corresponding coating adhesive, followed by adding each inoculant in a modified pan granulator until each seed was covered with a uniform layer of coated materials. The proportion of adhesive: solid inoculant carrier: seed (1:2:20 by weight or volume) was employed. The coated seeds were then air-dried under controlled laboratory conditions $\left(25^{\circ} \mathrm{C}\right.$ and $60 \% \mathrm{RH}$ ) for 72 hours and then stored before use. The coated seeds at an appropriate number (100 seeds) were then packed in a heat-sealed polyethylene bag and used for laboratory storage study (addressed as laboratory experiment). The others were employed for the field experiment.

\section{F. Laboratory Experiment}

A laboratory experiment was conducted at the Agronomy Laboratory and Plant Protection Laboratory, Bengkulu University, Bengkulu. The purpose of this trial was to determine which the seed coating formulations best maintains the survival of $R$. phaseoli population on the surface of coated bean seed based on CFU count at an interval of 24 hours for a storage period of 48 hours at $40^{\circ} \mathrm{C}$. The study on the survival of $R$. phaseoli on the surface of coated seeds was conducted with the 12 coating formulations as the first factor and a storage period as the second factor. The storage period was expressed as 0,24 , and 48 hours after inoculation (HAI). The experiment applied a Split Plot Design with three replications with the storage period as the main plot and the coating formulations as a subplot. From the 12 coating formulations, seed coated with $\mathrm{SCF}_{1}$ was assigned as a control treatment.

Soon after seed coating inoculation, each treatment of inoculated seeds was split into three lots of equal size with 100 coated seeds in each lot with each lot designated as a repetition. Each seed lot was then placed in a low-density polypropylene bag and stored for 48 hours at $40^{\circ} \mathrm{C}$ under room conditions. During the storage period, a coated seed sample from each treatment and replication was taken at an interval of 24 hours. Thus, the coated seed sample was withdrawn at 0,24 , and $48 \mathrm{HAI}$. Then, the number of viable cells resisting on the surface of the coated seed was determined on sampled seed [45] and expressed as CFU. The following equation calculated the CFUs.

$$
C F U / m l=\left(\frac{\sum N}{P \times(1 / A) \times(1 / D)}\right)
$$

Where $N$ is the number of colonies/plate, $P$ is the number of dishes, $A$ is the amount (in $\mathrm{ml}$ ) of the aliquot, and $1 / D$ is the decimal dilution.

To count the CFU, a subsample often coated seeds from each treatment combination, and replicate was withdrawn and transferred in a 250-ml Erlenmeyer flask containing 10 $\mathrm{ml}$ of sterile $0.85 \%(\mathrm{w} / \mathrm{v}) \mathrm{NaCl}+0.01 \%(\mathrm{w} / \mathrm{v})$ Tween 80 solution. The bottle was then agitated in an orbital shaker at $150 \mathrm{rpm}$ for 15 minutes. Through severe agitation, bacteria initially attached to the seed cuticle were separated entirely and gone into the solution. Then, $1.0 \mathrm{ml}$ of the solution was taken, and ten-fold serial dilution in sterile $0.85 \%(\mathrm{w} / \mathrm{v})$ $\mathrm{NaCl}$ was prepared. About $100 \mu \mathrm{l}$ of each dilution from each series were placed onto Petri dishes supplementing with Congo-red/YEM agar and $5.0 \mu \mathrm{g}$ of cycloheximide per $\mathrm{ml}$. The inoculated plates were stored at $28^{\circ} \mathrm{C}$ for seven days, then the assessment of the rhizobia colonies was conducted. The result was indicated by the number of viable rhizobia per seed basis (CFU seed ${ }^{-1}$ ). This process was repeated at each interval of 24 hours for a storage period of 48 hours. 


\section{G. Field Experiment}

A field study was conducted at the Agriculture Faculty Research Plot Bengkulu University, Bengkulu, in a redyellow podzolic soil to evaluate which the seed coating formulations best promotes common bean growth and yield. The characteristics of the experimental area were presented in Table II. The treatments were arranged in a single factor of Completely Randomized Design (CRD) with three replications. The treatments consisted of the 12 seed coating formulations plus non-inoculated seed coating $\left(\mathrm{SCF}_{0}\right)$ as a control treatment. Inoculated seed coating used in this study was the same as those used in the first experiment.

TABLE II

THE CHARACTERISTICS OF EXPERIMENTAL AREA

\begin{tabular}{|l|r|r|}
\hline Soil Properties & \multicolumn{2}{c|}{ Replications } \\
\hline & $\mathbf{1}$ & $\mathbf{2}$ \\
\hline $\mathrm{pH}$ & 4.90 & 5.00 \\
\hline $\mathrm{P}_{2} \mathrm{O}_{5}(\mathrm{ppm})$ & 12.46 & 11.83 \\
\hline $\mathrm{CEC}\left({\left.\mathrm{me} 100 \mathrm{~g}^{-1}\right)}^{-1}\right.$ & 14.77 & 12.20 \\
\hline Soil Texture & \multicolumn{3}{|c|}{ Sandy Loam } \\
\hline
\end{tabular}

Before inoculated seeds were planted, the land was prepared by conventional practice to make the field suitable for planting. The area was leveled and divided into blocks and individual plots. Each plot was made with a size of 1.35 $\mathrm{m} \times 2.55 \mathrm{~m}$. The plots were kept $0.50 \mathrm{~m}$ apart, with $1.0 \mathrm{~m}$ spacing between blocks.

All seeds were sown in the individual plot after ploughing, harrowing. Lime ( 2 ton of lime $\mathrm{ha}^{-1}$ ) was applied at two weeks before sowing. A basal fertilizer was applied to all the plots at $60 \mathrm{~kg} \mathrm{P}_{2} \mathrm{O}_{5} \mathrm{ha}^{-1}$ as triple superphosphate, $120 \mathrm{~K}_{2} \mathrm{O}$ $\mathrm{ha}^{-1}$ as $\mathrm{KCl}$, and 10 ton $\mathrm{ha}^{-1}$ goat manure. The nutrient content of goat manure was showed in Table III. Nitrogen fertilization $\left(40 \mathrm{~kg} \mathrm{ha}^{-1}\right)$ after sowing was added to plots as ammonium nitrate $(33 \%)$.

Two coated bean seeds were planted at a spacing of $50 \mathrm{~cm}$ between plants and $100 \mathrm{~cm}$ between rows. Uninoculated seeds were planted first in control plots. After sowing, coated seeds were protected from exposing the sun's radiation by covering them with soil to avoid the death of bacterial cells. Two weeks after seed germinated, plants were thinned, and only one plant was left.

TABLE III

THE CHARACTERISTICS OF GOAT MANURE

\begin{tabular}{|l|l|}
\hline Chemical characteristics & Nutrient content \\
\hline Total-N $(\%)$ & 0.53 \\
\hline $\mathrm{P}_{2} \mathrm{O}_{5}(\%)$ & 0.38 \\
\hline $\mathrm{K}_{2} \mathrm{O}(\%)$ & 0.20 \\
\hline $\mathrm{Ca}(\%)$ & 0.30 \\
\hline $\mathrm{Mg}(\%)$ & 0.15 \\
\hline
\end{tabular}

At mid-flowering (50\% flowering), five plants were withdrawn randomly from the second border of each plot as sample plants. The whole plant was excavated carefully to get complete roots and nodules for nodulation evaluation and dry weight of plants. The lump of the soil was removed from plant roots by rinsing in running water. Root nodules were removed carefully. The five plants from each plot were utilized to record the number of nodules per plant.

Bean plants were harvested from each plot at the maturity stage, leaving the border rows and $0.5 \mathrm{~m}$ length on every end of each row. Grain yield was determined by adjusting the moisture level to $13 \%$. After recording the grain yield, for each plot, five plants were withdrawn randomly from the central rows and oven-dried at $70^{\circ} \mathrm{C}$ to constant weight to calculate above-ground dry matter yield.

\section{H. Statistical Analysis}

For the laboratory study, a two-way analysis of variance (ANOVA) was employed to test the impacts of seed coating formulations, storage periods, and their interactions on the CFUs. The differences between storage period treatments at each level of seed coating formulation were compared using LSD test $(\mathrm{P} \leq 0.05)$, while Duncan's comparison of multiple variables was performed for the different seed coating formulation treatments at various levels of storage period $(\mathrm{P} \leq 0.05)$. For the field experiment, one-way ANOVA was used to test which the seed coating formulations best promotes plant dry weight, number of nodules, and grain yield. The differences between seed coating formulation treatments were compared using Duncan's comparison $(\mathrm{P} \leq 0.05)$.

\section{RESULTS AND DISCUSSION}

Analysis of the data of viable cells based on CFU count from the laboratory study demonstrated that significant differences $(\mathrm{P} \leq 0.05)$ were observed for seed coating formulations, storage period, and their interactions. At 0 HAI, the number of viable cells (CFU) seed $^{-1}$ showed no significant differences irrespective of seed coating formulations. The CFUs remained nearly constant or reduced only slightly (>10 $10^{7}$ viable cells seed $^{-1}$ ). This result indicated that a viable number of $R$. phaseoli cells has not much deteriorated due to high temperatures during storage. Also, sufficient inoculant was firmly attached to the surface of seeds irrespective of seed coating formulations (Table IV). At this period of storage, the bacterial cells were experiencing an adaptive period to the new environment since the biochar-based solid carriers provided different characteristics from those found in the liquid culture where bacterial cells were initially generated.

As the storage period was prolonged to $24 \mathrm{HAI}$, the CFUs dropped regardless of seed coating formulations. At this storage period, the population of $R$. phaseoli reduced one to two orders of magnitude (1 to $2 \operatorname{logs}$ ) concerning the initial bacteria, depending on the seed coating formulations (Table IV). The remaining viable-cell counts for each seed coating formulation differed, depending on adhesive agents used. For instance, the seed coating formulation containing GA as an adhesive such as $\mathrm{SCF}_{1}$ and $\mathrm{SCF}_{4}$, or $\mathrm{CMC}$ as an adhesive such as $\mathrm{SCF}_{5}$ and $\mathrm{SCF}_{8}$ at this period of storage preserved high viable cells enough to guarantee a high number of nodule formation $\left(10^{5}\right.$ to $10^{6}$ bacteria seed $\left.^{-1}\right)$ while the viability of bacterial population for $\mathrm{SCF}_{9}-\mathrm{SCF}_{12}$ containing sucrose as an adhesive dropped to below standard.

When the storage period was extended to $48 \mathrm{HAI}$, the decrease in the number of viable cells on inoculated seeds continued to occur except for $\mathrm{SCF}_{1}, \mathrm{SCF}_{4}, \mathrm{SCF}_{5}$, and $\mathrm{SCF}_{8}$ (Table IV). The decline in the bacterial population in the surface of coated seeds at 48 HAI was more evident than that at 24 HAI. These results confirmed that stressful environments such as exposure to high storage temperature 
even in a short time, which simulated high soil temperature in the much tropical soil, could be a limiting factor for the survival of the applied bacterial population. A similar reason was also described by a previous study [28].

TABLE IV

SUMMARY OF SIGNIFICANCES OF THE SOURCES OF VARIATION IN THE ANALYSIS OF VARIANCE ON THE SURVIVAL OF BEAN RHIZOBIA ON INOCULATED SEEDS STORED AT $40^{\circ} \mathrm{C}$

\begin{tabular}{|c|c|c|c|}
\hline \multirow{2}{*}{$\begin{array}{l}\text { Seed } \\
\text { Coating } \\
\text { Formula }\end{array}$} & \multicolumn{3}{|c|}{ Survival $\left[\log _{10}\right]$ CFU seed ${ }^{-1}$ after hours: } \\
\hline & $\mathbf{0}^{(1)}$ & 24 & 48 \\
\hline $\mathrm{SCF}_{1}$ & $7.29 \mathrm{aA}$ & $6.24 \mathrm{aB}$ & $5.71 \mathrm{aB}$ \\
\hline $\mathrm{SCF}_{2}$ & $7.24 \mathrm{aA}$ & $5.18 \mathrm{bB}$ & $3.30 \mathrm{bC}$ \\
\hline $\mathrm{SCF}_{3}$ & $7.07 \mathrm{aA}$ & $5.13 \mathrm{bB}$ & $3.48 \mathrm{bC}$ \\
\hline $\mathrm{SCF}_{4}$ & $7.03 \mathrm{aA}$ & $6.11 \mathrm{aB}$ & $5.67 \mathrm{aB}$ \\
\hline $\mathrm{SCF}_{5}$ & $7.06 \mathrm{aA}$ & $6.01 \mathrm{aB}$ & $5.50 \mathrm{aB}$ \\
\hline $\mathrm{SCF}_{6}$ & $7.01 \mathrm{aA}$ & $5.05 \mathrm{bB}$ & $3.40 \mathrm{bC}$ \\
\hline $\mathrm{SCF}_{7}$ & $7.11 \mathrm{aA}$ & $5.25 \mathrm{bB}$ & $3.66 \mathrm{bC}$ \\
\hline $\mathrm{SCF}_{8}$ & $7.00 \mathrm{aA}$ & $6.00 \mathrm{aB}$ & $5.57 \mathrm{aB}$ \\
\hline $\mathrm{SCF}_{9}$ & $7.16 \mathrm{aA}$ & $4.49 \mathrm{cB}$ & $3.34 \mathrm{bC}$ \\
\hline $\mathrm{SCF}_{10}$ & $7.11 \mathrm{aA}$ & $4.01 \mathrm{cB}$ & $3.30 \mathrm{bC}$ \\
\hline $\mathrm{SCF}_{11}$ & $7.03 \mathrm{aA}$ & $4.03 \mathrm{cB}$ & $3.57 \mathrm{bC}$ \\
\hline $\mathrm{SCF}_{12}$ & $7.05 \mathrm{aA}$ & $4.41 \mathrm{cB}$ & $3.43 \mathrm{bC}$ \\
\hline
\end{tabular}

(1) Means followed by equal letters, lower case in columns upper case in rows, did not differ by the LSD and DMRT at $\mathrm{P} \leq 0.05$, respectively.

The four seed coating formulations $\left(\mathrm{SCF}_{1}, \mathrm{SCF}_{4}, \mathrm{SCF}_{5}\right.$, and $\mathrm{SCF}_{8}$ ) were consistently able to maintain a high number of viable cells at both 24 and 48 HAI. They provided about $4.70 \times 10^{5}$ rhizobia seed $^{-1}$. These numbers exceeded with a

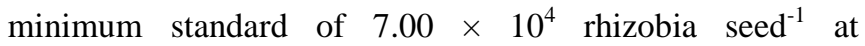
inoculation [47]. Interestingly, based on carriers composition used, PM (100\%) was employed for $\mathrm{SCF}_{1}$ and $\mathrm{SCF}_{4}$, and $\mathrm{BC}+\mathrm{PM}(25 \%: 75 \%)$ for $\mathrm{SCF}_{4}$, respectively. Meanwhile, based on adhesive agents used $\mathrm{SCF}_{1}$ and $\mathrm{SCF}_{4}$ contained GA, while $\mathrm{SCF}_{5}$ and $\mathrm{SCF}_{8}$ involved $\mathrm{CMC}$. These results suggest that $\mathrm{BC}+\mathrm{PM}(25 \%: 75 \%)$ mixture was as effective as PM $(100 \%)$ in promoting rhizobia survival on the surface of coated seeds when GA and CMC were applied as an adhesive.

The good promoting effect of $\mathrm{SCF}_{1}$ and $\mathrm{SCF}_{5}$ on the bacterial cell population of coated seed was not surprised because the initial $\mathrm{pH}$ of $\mathrm{PM}$ in both coating formulations was adjusted to neutral with the addition of $\mathrm{CaCO}_{3}$. With this $\mathrm{pH}$ modification, it indicated that $\mathrm{pH}$ is known as a crucial factor that controls bacterial viability, in agreement with the finding by [38]. The treatment of $\mathrm{SCF}_{4}$ and $\mathrm{SCF}_{8}$ also supported the bacterial survival on the surface of coated seed because the $\mathrm{pH}$ of $\mathrm{BC}+\mathrm{PM}(25 \%: 75 \%)$ was 6.38 , an optimal $\mathrm{pH}$ for rhizobia growth. The initial $\mathrm{pH}$ of $\mathrm{PM}$ for this carrier composition was not calibrated to neutral. Biochar $\mathrm{pH}$ might be considered to have a significant effect on total microbial abundance [24], [38]. A neutral $\mathrm{pH}$ of 5.5- 7.0 had been reported to be optimal for the growth medium of most beneficial bacteria [38]. Therefore, it was expected that carriers close to this $\mathrm{pH}$ (especially $\mathrm{SCF}_{1}$, $\mathrm{SCF}_{4}, \mathrm{SCF}_{5}$, and $\mathrm{SCF}_{8}$ ) would sustain the number and viability of $R$. phaseoli at higher levels than the other carriers when combined with GA or CMC. Surprisingly, the coating formulations made up of $\mathrm{BC}(100 \%)$ or $\mathrm{BC}+\mathrm{PM}$ (50\%:50\%) as a carrier irrespective of adhesive agents used did not support high numbers of the bacterial cell population.
These results suggest that $\mathrm{BC}(100 \%)$ or $\mathrm{BC}+\mathrm{PM}(50 \%: 50 \%)$ was not classified as a suitable carrier because the $\mathrm{pH}$ values were 8.25 for $\mathrm{BC}(100 \%)$ and 7.40 for $\mathrm{BC}+\mathrm{PM}(50 \%: 50 \%)$, respectively. Therefore, these $\mathrm{pH}$ values were not optimal for bacterial cell growth [24]. Although peat stays the best of all inoculant carriers, $\mathrm{BC}+\mathrm{PM}(25 \%: 75 \%)$ mixture can be used as an alternative carrier to peat. With this mixture as an inoculant carrier, the high survival of $R$. phaseoli on the surface of coated seeds was successfully conserved.

Proper maintenance of living and active bacterial cells on the surface of coated seed not only depends on $\mathrm{pH}$ carrier but also adhesive agents used [21]. Previous studies reported that good adhesives not just stick the inoculant to the seed firmly but also maintained a high number of bacterial viability on the surface of coated seeds [24],[28],[38]. Results from this laboratory study showed that when combined with PM $(100 \%)$ or BC+PM $(25 \%: 75 \%)$, GA and CMC ensured much better bacterial cell survival than did SC (Table IV). Thus, GA and CMC were categorized as better coating adhesives than SC. Excellent adhesive properties include a proper attachment of inoculant to seed, excellent protection for bacterial cells against stressful conditions, and a source of energy for bacterial food [24], [38]. In this study, GA and CMC indeed met all these three functions, as indicated by maintaining high numbers of bacterial cell survival $\left(>10^{5}\right)$. Whereas SC was classified as a weak adhesive agent due to its failure to preserve bacterial cell survival as demonstrated by lower viable bacterial cell per seed $\left(<10^{5}\right)$ regardless of carrier compositions used.

The final test to verify the field performance of seed coating formulations is the evaluation of plant growth and yield. The results showed that seed coating formulations had significant effects on nodule number, plant dry weight, and grain yield (Table V). Seed coating formulations $\mathrm{SCF}_{1}, \mathrm{SCF}_{4}$, $\mathrm{SCF}_{5}$, and $\mathrm{SCF}_{8}$, resulted in the highest number of nodules plant $^{-1}$, over 16 nodules plant ${ }^{-1}$, plant dry weight, and grain yield, in agreement with their ability to maintain the survival of bacterial cells on the surface of the coated seed. Previous studies also reported that seed inoculation with beneficial microbes via seed coating enhanced the growth and yield of corn [24], soybean [38], alfalfa [28], and wheat [25]. In promoting the three plant growth indicators, $\mathrm{SCF}_{4}, \mathrm{SCF}_{5}$, and $\mathrm{SCF}_{8}$ were as effective as $\mathrm{SCF}_{1}$ as a reference treatment. Therefore, the use of $\mathrm{BC}+\mathrm{PM}(25 \%: 75 \%)$ as a carrier for the application of $R$. phaseoli via seed coating with GA or CMC as an adhesive could be a substitute for PM, which experiences diminishing reserves.

The highest biomass production and also grain yield attained by $\mathrm{SCF}_{1}, \mathrm{SCF}_{4}, \mathrm{SCF}_{5}$, and $\mathrm{SCF}_{8}$ was related to their modulation characteristic. More significant nodule number was accountable for a substantial increase in biomass production and grain yield. Similar results were also demonstrated by Glodowska et al. [38] in soybean. The other coating formulations which could not stimulate the three plant growth indicators might be due to their failure to promote Rhizobia survival on the surface of coated seeds. They were formulated by including SC irrespective of biochar-based carriers used. For examples, $\mathrm{SCF}_{9}-\mathrm{SCF}_{12}$, which contain SC as an adhesive, resulted in the lowest number of the three plant growth indicators (Table V). 
TABLE V

SUMMARY OF SIGNIFICANCES OF THE SOURCES OF VARIATION IN THE ANALYSIS OF VARIANCE ON THE SURVIVAL OF BEAN RHIZOBIA ON INOCULATED SEEDS STORED AT $40^{\circ} \mathrm{C}$

\begin{tabular}{|c|c|c|c|}
\hline $\begin{array}{l}\text { Coating } \\
\text { Formulations }\end{array}$ & $\begin{array}{l}{ }^{(1)} \text { Number of } \\
\text { Nodules } \\
\text { Plant }^{-1}\end{array}$ & $\begin{array}{l}{ }^{(1)} \text { Plant Dry } \\
\text { Weight } \\
\left(\text { g plant }^{-1}\right)\end{array}$ & $\begin{array}{l}{ }^{(1)} \text { Grain } \\
\text { Yield } \\
\left(\mathrm{g} \mathrm{m}^{-2}\right)\end{array}$ \\
\hline $\mathrm{SCF}_{0}$ & $9.10 \mathrm{~d}$ & $12.13 \mathrm{~d}$ & $67.9 \mathrm{~d}$ \\
\hline $\mathrm{SCF}_{1}$ & $16.45 \mathrm{a}$ & $21.24 \mathrm{a}$ & $107.6 \mathrm{a}$ \\
\hline $\mathrm{SCF}_{2}$ & $11.70 \mathrm{c}$ & $16.24 \mathrm{~b}$ & $90.6 \mathrm{~b}$ \\
\hline $\mathrm{SCF}_{3}$ & $13.70 \mathrm{~b}$ & $16.69 \mathrm{~b}$ & $90.6 \mathrm{~b}$ \\
\hline $\mathrm{SCF}_{4}$ & $16.40 \mathrm{a}$ & $21.78 \mathrm{a}$ & $106.2 \mathrm{a}$ \\
\hline $\mathrm{SCF}_{5}$ & $16.15 \mathrm{a}$ & $21.30 \mathrm{a}$ & $104.6 \mathrm{a}$ \\
\hline $\mathrm{SCF}_{6}$ & $11.00 \mathrm{c}$ & $16.35 \mathrm{~b}$ & $88.4 \mathrm{~b}$ \\
\hline $\mathrm{SCF}_{7}$ & $13.20 \mathrm{~b}$ & $17.15 \mathrm{~b}$ & $86.4 \mathrm{~b}$ \\
\hline $\mathrm{SCF}_{8}$ & $16.00 \mathrm{a}$ & $21.39 \mathrm{a}$ & $111.6 \mathrm{a}$ \\
\hline $\mathrm{SCF}_{9}$ & $9.40 \mathrm{~d}$ & $14.60 \mathrm{c}$ & $75.2 \mathrm{c}$ \\
\hline $\mathrm{SCF}_{10}$ & $9.25 \mathrm{~d}$ & $14.53 \mathrm{c}$ & $77.2 \mathrm{c}$ \\
\hline $\mathrm{SCF}_{11}$ & $9.20 \mathrm{~d}$ & $14.24 \mathrm{c}$ & $75.4 \mathrm{c}$ \\
\hline $\mathrm{SCF}_{12}$ & $9.20 \mathrm{~d}$ & $14.30 \mathrm{c}$ & $76.8 \mathrm{c}$ \\
\hline
\end{tabular}

(1) Means followed by equal letters, lower case in columns did not differ by the DMRT at $\mathrm{P} \leq 0.05$.

Sucrose (SC) was classified as a weak adhesive and may contribute to the lowest values of the three plant growth measurements. These coating formulations were as bad as $\mathrm{SCF}_{0}$ (non-inoculated and non-coated seed). The other factor triggering the failure to maintain the bacterial population on the surface of coated seed was related to carrier $\mathrm{pH}$. Data presented in Table $\mathrm{V}$ demonstrated that the Rhizobia seedcoating formulations $\left(\mathrm{SCF}_{2}, \mathrm{SCF}_{3}, \mathrm{SCF}_{6}, \mathrm{SCF}_{7}, \mathrm{SCF}_{10}\right.$, and $\left.\mathrm{SCF}_{11}\right)$, which contain $\mathrm{BC}(100 \%)$ or $\mathrm{BC}+\mathrm{PM}(50 \%: 50 \%)$ irrespective adhesive agents used failed to improve nodule number, plant dry weight, and grain yield. The two carriers had a $\mathrm{pH}$ value of 8.25 for $\mathrm{BC}(100 \%)$ and 7.40 for $\mathrm{BC}+\mathrm{PM}$ (50\%:50\%), respectively.

\section{CONCLUSIONS}

Four SCFs were the best for Rhizobia survival throughout the storage period. The four SCFs contained a combination of GA and PM (100\%), GA and PM+BC (25\%:75\%), CMC and $\mathrm{PM}(100 \%)$, and $\mathrm{CMC}$ and $\mathrm{PM}+\mathrm{BC}$ (25\%:75\%), respectively. In parallel with their best capacity for Rhizobia viability, these four Rhizobia seed-coating formulations also best-promoted plant growth and yield based on nodule number, plant dry weight, and grain yield indicators. Seed coating formulations with SC as an adhesive regardless of the biochar-based carrier used or BC $(100 \%)$ or $\mathrm{BC}+\mathrm{PM}$ (50\%:50\%) as a carrier irrespective of adhesive agents used were not recommended.

\section{REFERENCES}

[1] D. Nyfeler, O. Huguenin-Elie, M. Suter, E. Frossard, and A. Lüscher, "Grass-legume mixtures can yield more nitrogen than pure legume stands due to mutual-stimulation of nitrogen uptake from symbiotic and nonsymbiotic sources," Agric. Ecosyst. Environ., vol. 140, pp. 155-163, 2011.

[2] O. Alberton, G. Kaschuk, and M. Hungria, "Sampling effects on the assessment of genetic diversity of rhizobia associated with soybean and common bean," Soil Biol. Biochem., vol. 38, pp. 1298-1307, 2006

[3] W. Broughton, G. Hernandez, M. Blair, S. Beebe, P. Gepts, and J. Vanderleyden, "Beans (Phaseolus spp.): Model food legumes," Plant Soil, vol. 252, pp. 55-128, 2003.
[4] J. De Luque, J. Rodríguez, and C. Bernardo, "Major constraints and trends for common bean production and commercialization: Establishing priorities for future research," Agron. Colomb., vol. 32, 423-431, 2014.

[5] Direktorat Jenderal Hortikultura, "Statistik Produksi Hortikultura Tahun 2014," Jakarta: Direktorat Jenderal Hortikultura-Kementerian Pertanian, 2015.

[6] S. E. Beebe, I. M. Rao, A. M. J. Devi, and J. Polania, "Common beans, biodiversity, and multiple stresses: Challenges of drought resistance in tropical soils," Crop Past. Sci., vol. 65, pp. 667-675, 2014 .

[7] M. Malagnoux. (2007) Arid land forest of the world: Global environmental perspectives. [Online]. Available http://www.fao.org/3/a-ah836e.pdf/

[8] G. W. Mmbaga, K. M. Mtei, and P. A. Ndakidemi, "Extrapolations on the use of Rhizobium inoculants supplemented with phosphorus (P) and potassium $(\mathrm{K})$ on growth and nutrition of legumes," Agric. Sci., vol. 5, pp. 1207-1226, 2014.

[9] S. Savci, "An agricultural pollutant: Chemical fertilizer international," J. Environ. Sci. Develop., vol. 3, pp. 77-80, 2012.

[10] Y. Luo, M. Durenkamp, M. DeNobili, Q. Lin, B.J. Devonshire, and P.C. Brookes, "Microbial biomass growth, following incorporation of biochars produced at $350^{\circ} \mathrm{C}$ or $700^{\circ} \mathrm{C}$, in a silty-clay loam soil of high and low pH," Soil Biol. Biochem., vol. 57, pp. 513-523, 2013.

[11] C. Freire, R. J. Koifman, and S. Koifman, "Hematological and hepatic alterations in Brazillian population heavily exposed to organochlorine pesticide," J. Toxicol. Environ. Health A, vol. 78, pp. 534-548, 2015

[12] A. K. Tripti, U. Zeba, K. Vipin, and Anshumali, "Biochar and flyash inoculated with plant growth promoting rhizobacteria act as potential biofertilizer for luxuriant growth and yield of tomato plant," $J$. Environ. Manag., vol. 190, pp. 20-27, 2017.

[13] B. Roshanravan, S. M. Soltani, S. A. Rashid, F. Mahdavi, and M. K. Yusop, "Enhancement of nitrogen release properties of urea-kaolinite fertilizer with chitosan binder," Chem. Spec. Bioavail., vol. 27, pp. 44-51, 2015.

[14] N. Ameloot, S. DeNeve, K. Jegajeevagan, G. Yildiz, D. Buchan, Y.N. Funkuin, W. Prins, L. Buckaert, and S. Sleutel, "Short-term $\mathrm{CO}_{2}$ and $\mathrm{N}_{2} \mathrm{O}$ emissions and microbial properties of biochar amended sandy loam soils", Soil Biol. Biochem., vol. 57, pp. 401-410, 2013.

[15] M.O. Callaghan, "Microbial inoculation of seed for improved crop performance: Issue and opportunities," Appl. Microbiol. Biotechnol., vol. 100, pp. 5729-5746, 2016.

[16] D. Nyfeler, O. Huguenin-Elie, M. Suter, E. Frossard, and A. Lüscher, "Grass-legume mixtures can yield more nitrogen than legume pure stands due to mutual-stimulation of nitrogen uptake from symbiotic and nonsymbiotic sources," Agric. Ecosyst. Environ., vol. 140, pp. 155-163, 2011.

[17] O. Alberton, G. Kaschuk, and M. Hungria, "Sampling effects on the assessment of genetic diversity of rhizobia associated with soybean and common bean," Soil Biol. Biochem., vol. 38, pp. 1298-1307, 2006.

[18] M. Hungria, and M.A.T. Vargas," Environmental factors affecting $\mathrm{N}_{2}$ fixation in grain legumes in the tropics, with emphasis on Brazil," Field Crop Exp., vol. 65, pp. 151-164, 2000.

[19] J. I. Vilchez, A. Navas, J. Gonzalez-Lopez, S. C. Arcos, and M. Manzanera, "Biosafety test for plant growth-promoting bacteria: proposed environmental and human safety index (EHSI)," Protoc. Front. Microbiol., vol. 6, pp. 1514, 2016.

[20] R. S. Araujo, T. N. Martin, M. A. Nogueira, S. P. da Cruz, E. L. Souchie, A. S. Nakatani, and M. Hungria, "Preinoculation of soybean seeds treated with agrichemicals up to 30 days before sowing: technological innovation for large-scale agriculture," Int. J. Microbiol., vol. 2017, 11 pages, 2017.

[21] R. Deaker, R.J. Roughley, and I.R. Kennedy, "Legume seed inoculation technology: A review", Soil Biol.Biochem., vol. 36, pp. 1275-1288, 2004

[22] D. Rivera, M. Obando, H. Barbosa, D. Rojas-Tapias, R. Bonilla Buitrago, "Evaluation of polymers for the liquid rhizobial formulation and their influence in the Rhizobium-Cowpea interaction," Univ. Sci., vol. 19, pp. 265-275, 2014.

[23] H. Mariangela, A. N. Marco, and S. A. Ricardo, "Alternative methods of soybean inoculation to overcome adverse conditions at sowing," African J. Agric. Res.,vol. 10, pp. 2329-2338, 2015.

[24] M. Glodowska, B. Husk, T. Schwinghame, and D. Smith, "Biochar is a growth-promoting alternative to peat moss for the inoculation of corn with a pseudomonad," Agron. Sustain. Dev. 36: 21, 2016. 
[25] R. S. Oliveira, I. Rocha, Y. Ma, M. Vosatka, and H. Freitas, "Seed coating with arbuscular mycorrhizal fungi as an ecotechnological approach for sustainable agricultural production of common wheat (Triticum aestivum L.)," J. Toxicol. Environ. Health, Part A, 2016.

[26] S. Ehsanfar, and S. A. Modarres-Sanavy, "Crop protection by seed coating," Commun. Agric. Appl. Biol. Sci., vol. 70, pp. 225-229, 2005 .

[27] P. Fernandes Jr., C. da Silva, P. de Oliveira, N. Rumjanek, L. Martins, and G. Xavier, "Performance of polymer compositions as carrier to cowpea rhizobial inoculant formulations: Survival of rhizobia in preinoculated seeds and field efficiency," African J. Biotechnol., vol. 11, pp. 2945-2951, 2012.

[28] J. Zhou, B. Deng, Y. Zhang, A. B. Cobb, and Z. Zhang, "Molybdate in rhizobial seed-coat formulations improves the production and nodulation of alfalfa. PLOS ONE, vol. 12, 2017.

[29] P. I. Fernandes Jr., T. G. Rohr, P.Jd. Oliveira, G. R. Xavier, and N. G. Rumjanek, "Polymers as carriers for rhizobial inoculant formulations," Pesquisa Agropecua Brasileira, vol. 44, pp. 1184$1190,2009$.

[30] R. A. Date, "Advances in inoculant technology: A brief review," Aust. J. Exp. Agr., vol. 41, pp. 321-325, 2001.

[31] D. K. Maheswari, R. C. Dubey, M. Agarwal, S. Dheeman, A. Aeron, and V. K. Bajpai, "Carrier based formulations of biocoenotic consortia of disease suppressive Pseudomonas aeruginosa KRP1 and Bacillus licheniformis KRB1," Ecol. Eng., vol. 81, pp. 272-277, 2015.

[32] D. Sun, L. Hale, and D. Crowley, "Nutrient supplementation of pinewood biochar for use as a bacterial inoculum carrier," Biol. Fertil. Soils, vol. 52, pp. 515-522, 2016.

[33] L. Hale, M. Luth, and D. Crowley, "Biochar characteristics relate to its utility as an alternative soil inoculum carrier to peat and vermiculite," Soil Biol. Biochem., vol. 81, pp. 228-235, 2015.

[34] G. Viveganandan, and K. S. Jauhri, "Growth and survival of phosphate solubilizing bacteria in calcium alginate," Microbiol. Res. vol. 155, pp. 205-207, 2000.

[35] A. Daza, C. Santamaria, D. N. Rodriguez-Navarro, M. Camacho, R. Orive, and F. Tempramo, "Perlite as a carrier for bacterial inoculants," Soil Biol. Biochem., vol. 32, pp. 567-572, 2000.

[36] S. J. Vanek, J. Thies, B. Wang, K. Hanley, and J. Lehmann, "Pore size and water activity effects on survival of Rhizobium tropici in biochar inoculant carriers," J. Microb. Biochem. Technol., vol. 8, pp. 296-306, 2016.

[37] A. A. Ghazi, "Potential for biochar as an alternative carrier to pea moss for the preparation of Rhizobia bioinoculum," Microb. Res. J. Int., vol. 18, pp.1-9, 2017.

[38] M. Glodowska, T. Schwinghamer, B. Husk, and D. Smith, "Biochar based inoculants improve soybean growth and nodulation," Agric., Sci., vol. 8, pp. 1048-1064, 2017.

[39] D. Egamberdieva, M. Reckling, and S. Wirth, "Biochar-based Bradyrhizobium inoculum improves growth of lupin (Lupinus angustifolius L.) under drought stress," European J. Soil Biol., vol. 78, pp. 38-42, 2017.

[40] J. Lehmann, "Bio-energy in the black," Front. Ecol. Environ., vol. 5 , pp. 381-387, 2007.

[41] K. B. Cantrell, P. G. Hunt, M. Uchimiya, J. M. Novak, and K. S. Ro, "Impact of pyrolysis temperature and manure source on physicochemical characteristics of biochar," Bioresource Technol., vol. 107, pp. 419-428, 2012.

[42] I. Kresnawaty, A. Budiani, dan T.W. Darmono, "Dinamika populasi Trichoderma harzianum DT38 pada campuran arang hayati tandan kosong kelapa sawit (TKKS) dan gambut," Menara Perkebunan, vol 80, pp. 17-24, 2012.

[43] [43] J. M. Vincent, J.M., 1970. A Manual for the Practical Study of the Root-Nodule Bacteria. Oxford: Blackwell Scientific Publications, 1970.

[44] R. A. Olsen, and L. R. Bakken, "Viability of soil bacteria: Optimization of plate-counting technique and comparison between total counts and plate counts within different size groups," Microb. Ecol., vol. 13, pp. 59-74, 1987.

[45] P. Somasegaran, and H. J. Heben, Handbook for Rhizobia: Methods in Legume-Rhizobium Technology, New York: Springer-Verlag, 1994.

[46] A. Kumar, and S. K. Maiti, "Effect of organic manures on the growth of Cymbopogon citratus and Chrysopogon zizanioides for the phytoremediation of chromiteasbestos mine waste: A pot scale experiment," Int. J. Phytorem., vol. 17, pp. 437-447, 2015.

[47] N. Z. Lupyawi, P. E. Olsen, E. S. Sande, H. H. Keyser, M. M. Collins, P. Singleton, and W. A. Rice, "Inoculant quality and its evaluation," Field Crops Res., vol. 65, pp. 259-270, 2000. 